\title{
Thermal-Hydrologic-Mechanical Study of Pre-Closure Off-Normal Thermal Scenarios at the Proposed Yucca Mountain Nuclear Waste Repository
}

\author{
Leem, J., Lin, M., Sun, Y., and Kicker, D.C. \\ Bechtel SAIC Company, Las Vegas, Nevada, USA \\ Damjanac, B. \\ Itasca Consulting Group, Minneapolis, Minnesota, USA
}

\begin{abstract}
The proposed nuclear waste repository at Yucca Mountain, Nevada currently includes a minimum of 50 years forced ventilation inside of emplacement drifts prior to repository closure. To regulate the heat generated from emplaced waste packages, the ventilation during the pre-closure period should be continuous. Off-normal thermal scenarios that consider temporary shutdown of the pre-closure ventilation are investigated to determine the impacts of ventilation shutdown on the thermal-hydrologic-mechanical behaviors of the emplacement drifts. In-drift heat transfer processes including radiation, convection, and conduction are studied. The analysis provides a ventilation heat removal ratio that varies on the drift location and the ventilation duration. The heat removal ratio is transferred and utilized in the NUFT thermal-hydrology software. The NUFT software is used to investigate the thermal-hydrologic impacts on the repository rock mass for the off-normal thermal scenarios with various shutdown durations at various pre-closure times. The predicted rock mass temperature evaluated from the thermalhydrologic analysis is applied for the thermal-mechanical analysis of the off-normal thermal scenarios. The results show that degradation and rockfall of the emplacement drifts due to the off-normal thermal scenarios will be minimal, and it is concluded that the impacts of off-normal thermal scenarios on the stability of the emplacement drifts will be insignificant.
\end{abstract}

\section{INTRODUCTION}

A geologic high-level nuclear waste repository was proposed by the U.S. Department of Energy at Yucca Mountain, Nevada. The proposed nuclear waste repository, located in mined geologic formations approximately $300 \mathrm{~m}$ deep, is subject to heat generated from emplaced nuclear waste packages. In order to regulate the heat from the waste packages, the proposed nuclear waste repository currently plans a minimum of 50 years forced ventilation in the emplacement drifts prior to repository closure. The intended ventilation should be continuous throughout the entire pre-closure period.

The normal thermal scenario (i.e., a minimum of 50 years continuous ventilation during the pre-closure period) has been studied in various reports $[1,2,3]$. The studies include thermal, thermal-hydrologic, and thermal-mechanical behaviors and performance of the emplacement drifts due to the continuous ventilation during the pre-closure period.

Off-normal thermal scenarios are investigated to assess the impacts of a temporary loss or shutdown of the ventilation on the thermal-hydrologicmechanical behaviors of the repository emplacement drifts. The off-normal thermal scenarios consider the temporary shutdown of the pre-closure ventilation (e.g., 1-day, 1-week, or 1month) at various pre-closure times (e.g., 2-year, 5year, and 10-year). The maximum duration of ventilation shutdown is assumed to be 1 month, since the loss of forced ventilation for as long as 30 days would be very unlikely [4]. Details of the thermal-hydrologic-mechanical study of the preclosure off-normal thermal scenario are presented in Scoping Analysis on Sensitivity and Uncertainty of Emplacement Drift Stability [5]. 


\section{APPROACH}

\subsection{Ventilation Thermal Analysis}

The normal thermal scenario with a 50-year continuous ventilation period is studied using the ANSYS finite element software [1]. In-drift heat transfer processes including radiation, conduction, natural convection, and ventilation (forced convection) are simulated to investigate effects of 50 years of continuous ventilation on the performance of the emplacement drifts.

A quasi 3-dimensional ventilation model is developed to simulate the in-drift pre-closure ventilation by coupling the radiation between the waste packages and the emplacement drift wall, the conduction of radiated heat into the surrounding rock mass, and the natural and forced convection inside of the emplacement drifts due to the ventilation. The ANSYS ventilation model investigates the effects of pre-closure ventilation on thermal conditions within the drift and the surrounding rock mass, and calculates efficiency of the ventilation in terms of a heat removal ratio during the pre-closure period.

Initially, the ANSYS ventilation model simulates the in-drift heat transfer processes in a 2dimensional section perpendicular to the emplacement drift at the ventilation air inlet (at 0$\mathrm{m})$. Initial and boundary conditions including ventilating airflow rate, thermal conductivity of the rock mass, and radiation emissivity and convective heat transfer coefficients of the waste packages and the rock mass are applied at the initial time step (at 0 -year).

A temperature-dependent correlation of mixed convection that includes both forced and natural convection was developed [6]. The correlation of mixed convection could provide the convective heat transfer coefficients of the waste package and the surrounding rock mass. The calculated convective heat transfer coefficients vary based on temperatures of the waste package, the emplacement drift wall, and the ventilation air at different time and axial locations of the drift. In order to incorporate the correlation of the mixed convection, a numerical scheme is developed to update the convective heat transfer coefficient at each time step and at the different axial locations of the drift in the ANSYS ventilation model [1].

Once the simulation of the pre-closure ventilation is started for the initial 2-dimensional emplacement drift section at the ventilation air inlet, the ANSYS ventilation model is updated with the new convective heat transfer coefficient of the waste package and the emplacement drift wall at each time step based on the temperature-dependent correlation of mixed convection.

To simulate the 3-dimensional emplacement drift, the 2-dimensional sections are connected to the previous sections using the ventilated air temperature and the convective heat transfer coefficients of the previous sections as inputs. Therefore, the ventilated air temperature and the convective heat transfer coefficients are kept updated along the axially located sections of the emplacement drift in the quasi 3-dimensional ANSYS ventilation model.

Investigation of the off-normal thermal scenarios could be conducted by reducing the efficiency of the pre-closure ventilation (i.e., the heat removal ratio) partially or more conservatively removing it entirely at certain time and for certain duration [5].

\subsection{Thermal-hydrologic Analysis}

Thermal-hydrologic behaviors of the proposed nuclear waste repository were studied using the NUFT thermal hydrology software [2]. NUFT was developed by Lawrence Livermore National Laboratory to simulate both saturated and unsaturated fluid flow, and transport in porous media under isothermal and non-isothermal conditions [7].

To simulate the thermal-hydrologic behaviors of the pre-closure emplacement drifts, the complex in-drift heat transfer processes (i.e., the radiation, the natural convection, and the forced convection) were simplified in terms of effective heat transfer from the waste packages into the rock mass. The effective heat transfer was calculated using the heat removal ratio from the results of the ANSYS ventilation model:

$$
Q_{w}^{\prime}=Q_{s}(1-\eta)
$$

where $Q_{w}^{\prime}$ is the effective heat transfer conducted into the rock mass (W), $Q_{s}$ is the heat generated from the waste package (W), and $\eta$ is the ventilation heat removal ratio. In-depth discussions on the application of the effective heat transfer is provided for the ANSYS ventilation model $[1,5]$, which demonstrates a reasonable prediction of temperature in and around the emplacement drifts. 
The NUFT thermal-hydrologic analysis [2] is adopted to investigate the thermal-hydrologic impacts on the rock mass around the emplacement drifts due to the off-normal thermal scenarios [5]. Simulation of the temporary shutdown of the preclosure ventilation is performed by employing the NUFT 2-dimensional drift-scale model. The 2dimensional drift-scale mode! simulates a location approximately at the geometric center of the proposed repository layout, which is adjacent to the ventilation air outlet approximately $600-\mathrm{m}$ from the ventilation air inlet. The repository horizon in the model is located in the middle of Topopah Spring Tuff lower lithophysal (Tptpll) zone, and is positioned approximately $310 \mathrm{~m}$ below the ground surface and $280 \mathrm{~m}$ above the water table. Examples of thermal-hydrologic properties of the Tptpll rock are presented in Table 1. Details of the thermalhydrologic properties of the Tptpll rock were provided in Multiscale Thermohydrologic Model [2]. The drift-scale model has a line-averaged heat source representing the waste packages inside the emplacement drift.

Table 1. Examples of thermal-hydrologic properties of the Tptpll rock [2]

\begin{tabular}{|c|c|c|c|}
\hline $\begin{array}{c}\text { Dry Bulk } \\
\text { Density } \\
\left(\mathrm{kg} / \mathrm{m}^{3}\right)\end{array}$ & $\begin{array}{c}\text { Wet Bulk } \\
\text { Thermal } \\
\text { Conductivity } \\
(\mathrm{W} / \mathrm{m}-\mathrm{K})\end{array}$ & $\begin{array}{c}\text { Dry Bulk } \\
\text { Thermal } \\
\text { Conductivity } \\
(\mathrm{W} / \mathrm{m}-\mathrm{K})\end{array}$ & $\begin{array}{c}\text { Grain } \\
\text { Specific } \\
\text { Heat } \\
(\mathrm{J} / \mathrm{kg}-\mathrm{K})\end{array}$ \\
\hline 1979 & 1.89 & 1.28 & 930 \\
\hline
\end{tabular}

The analysis of the off-normal thermal scenarios has various ventilation shutdown durations (e.g., 1day, 1-week, and 1-month) at various pre-closure times (e.g., 2-year, 5-year, and 10-year). The temporary shutdown of the pre-closure ventilation is simulated by setting the ventilation heat removal ratio to zero in Eq. (1). This modeling assumption is considered conservative, since natural convection is still accessible even after complete shutdown of the forced ventilation.

\subsection{Thermal-Mechanical Analysis}

Long-term performance of the proposed nuclear waste repository was studied by investigating thermal-mechanical behaviors and time-dependent degradation of the emplacement drift [3]. The study was conducted using both FLAC and UDEC software [8] including both the pre-closure periods under the normal thermal scenario and the postclosure period. In the analysis, mechanical properties of the Tptpll zone were assigned to 5 categories based on lithophysal porosity (Table 2). The rock mass temperature evaluated from the NUFT thermal-hydrologic analysis was used for predicting thermally induced stresses and long-term degradation of the rock mass around the drift.

Table 2. Mechanical properties and ranges of lithophysal porosity of the Tptpll zone [3]

\begin{tabular}{|c|c|c|c|}
\hline Category & $\begin{array}{c}\mathrm{UCS}^{1} \\
(\mathrm{MPa})\end{array}$ & $\begin{array}{c}\text { Estimated } \\
\text { Young's } \\
\text { Modulus (GPa) }\end{array}$ & $\begin{array}{c}\text { Approximated } \\
\text { Lithophysal } \\
\text { Porosity (\%) }\end{array}$ \\
\hline \hline 1 & 10 & 1.9 & $>25$ \\
\hline 2 & 15 & 6.4 & $20-25$ \\
\hline 3 & 20 & 10.8 & $15-20$ \\
\hline 4 & 25 & 15.3 & $10-15$ \\
\hline 5 & 30 & 19.7 & $<10$ \\
\hline
\end{tabular}

Unconfined Compressive Strength

A similar thermal-mechanical analysis is conducted for the pre-closure off-normal thermal scenarios [5]. The temperature of the rock mass around the emplacement drift is imported from the NUFT thermal-hydrologic analysis of the off-normal thermal scenarios, and used to assess thermalmechanical impacts of the temporary shutdown of the pre-closure ventilation on the rock mass around the emplacement drift.

\section{ANALYSIS AND RESULTS}

\subsection{Ventilation Thermal Analysis}

The ANSYS ventilation model for the normal thermal scenario provides temperatures of the waste package surface, the drift opening surface, and the ventilated air along the different axial locations of the emplacement drift at each time step. The model also provides efficiency of the pre-closure ventilation in terms of the heat removal ratio for both the drift axial locations and the ventilation time. Fig. 1 demonstrates temperature histories of the waste package surface, the drift opening surface, and the ventilated air at the end of the $600-\mathrm{m}$ emplacement drift. During the pre-closure period, temperatures of the waste package surface and the drift opening surface are generally below $90^{\circ} \mathrm{C}$ and $70{ }^{\circ} \mathrm{C}$, respectively. Fig. 2 presents the in-drift ventilation heat removal ratio during the pre-closure period at various drift axial locations. The heat removal ratio at $600-\mathrm{m}$ from the air inlet is used in the following NUFT thermal-hydrologic analysis. 


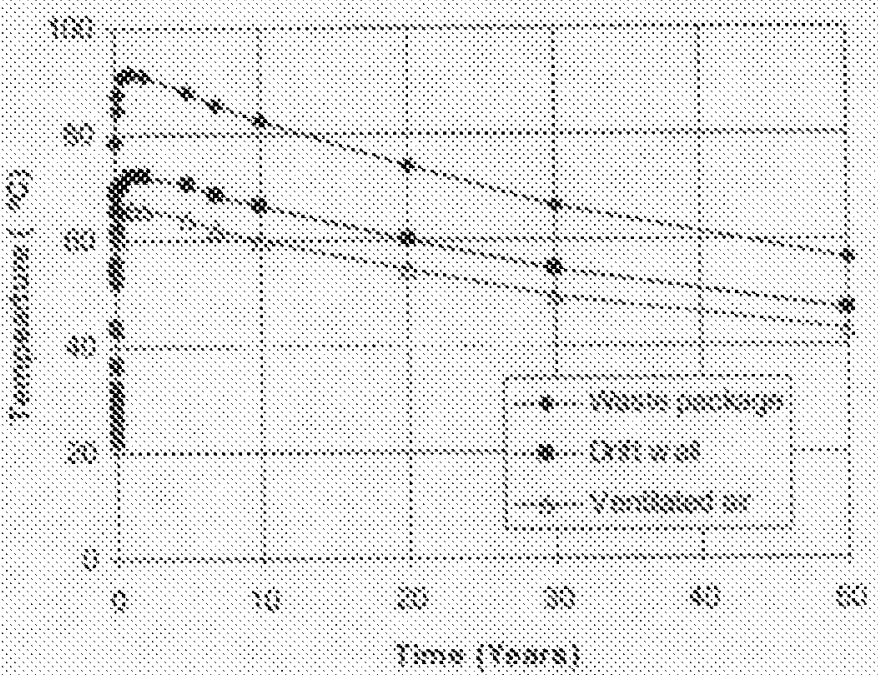

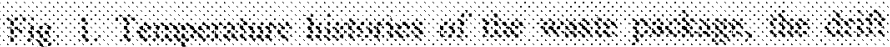

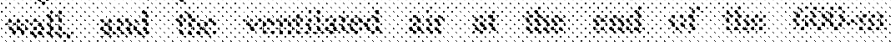

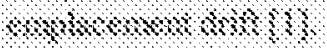

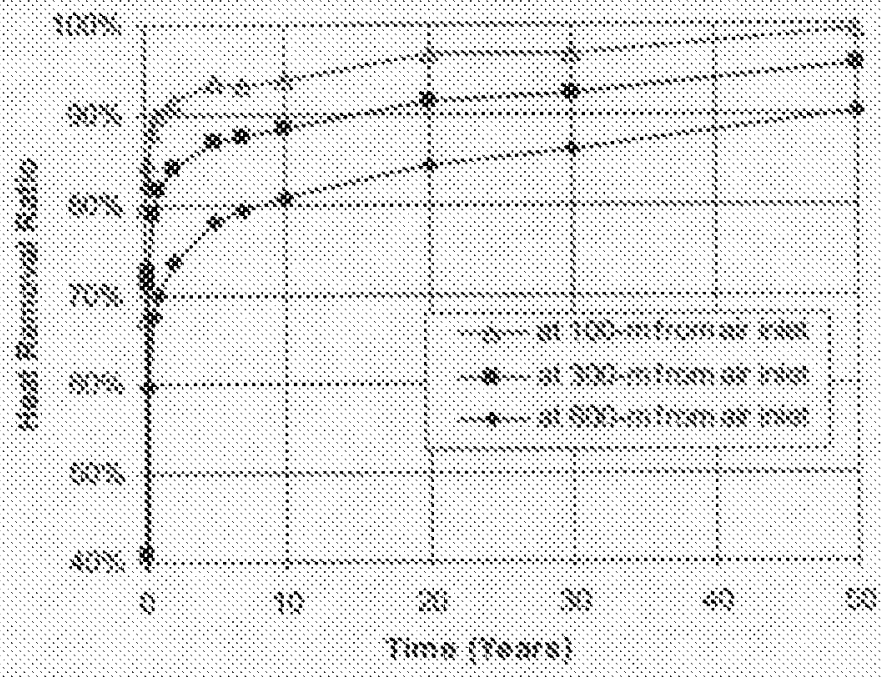

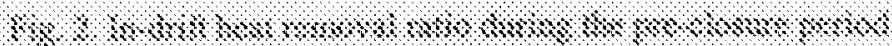

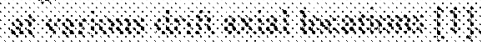

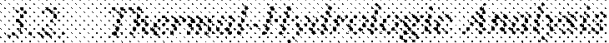

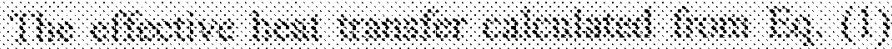

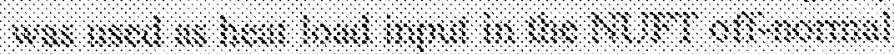

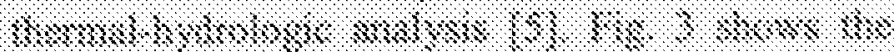

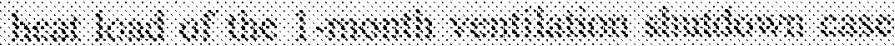

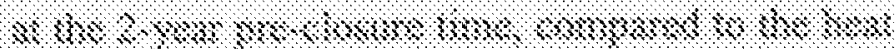

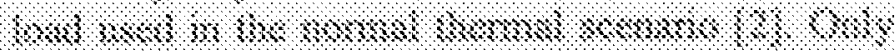

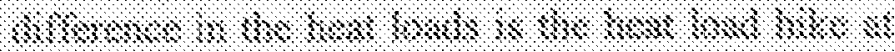

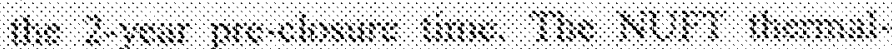

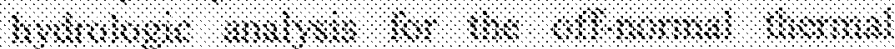

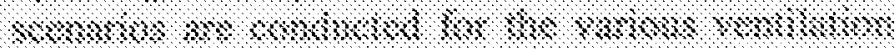

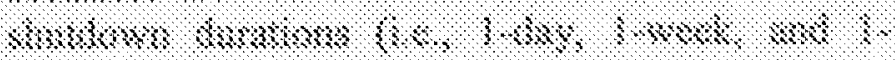

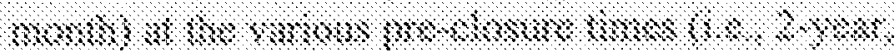

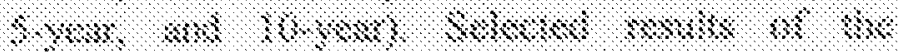

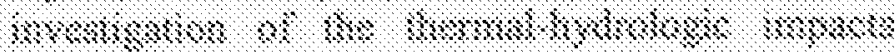

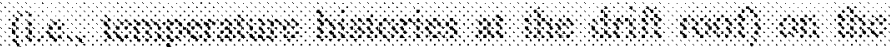
s.

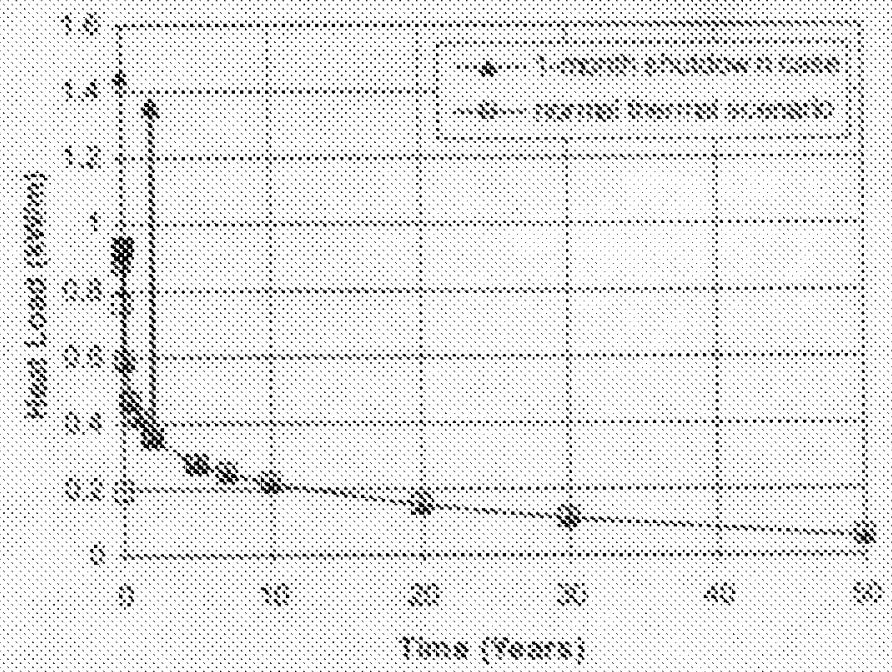

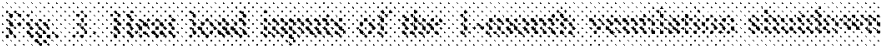

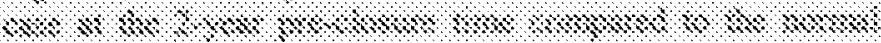
$\$, 1,3$,

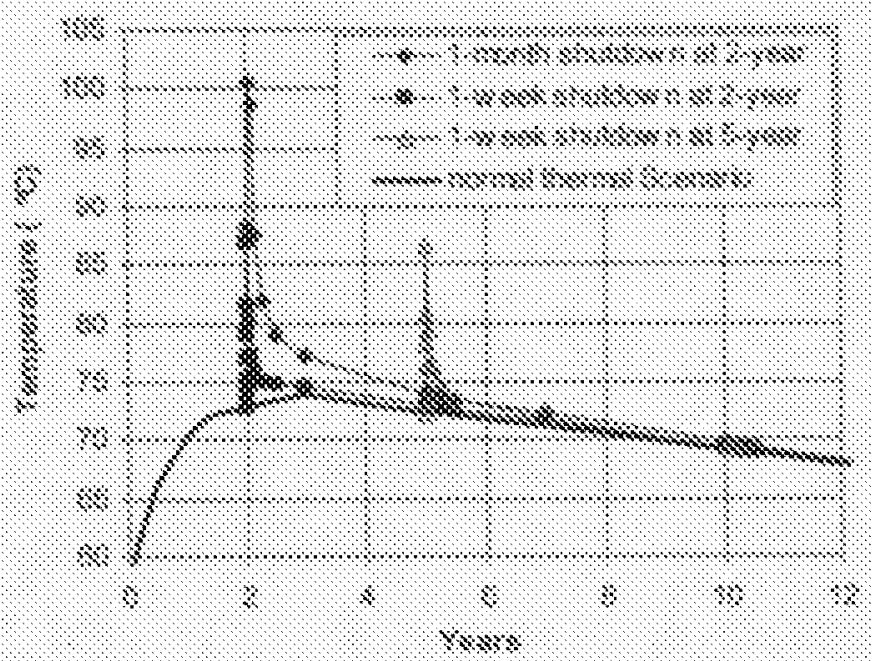

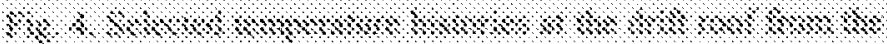
$\$, 1,0,0,0,0,3$

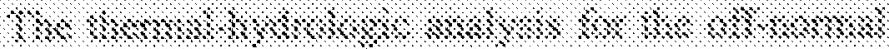

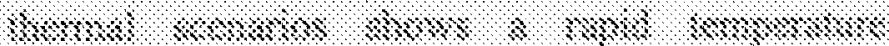

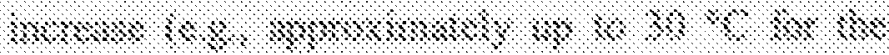

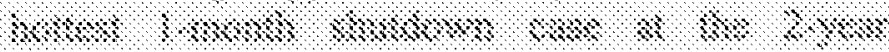

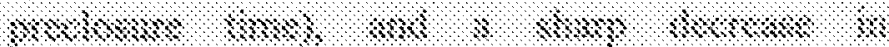

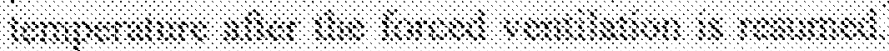

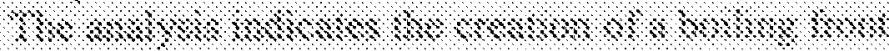

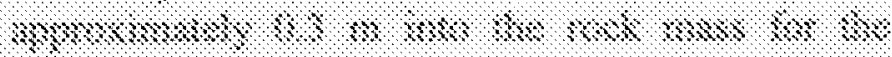

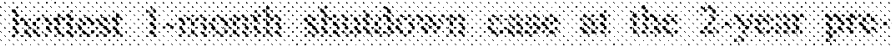

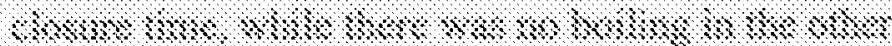

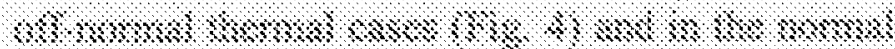

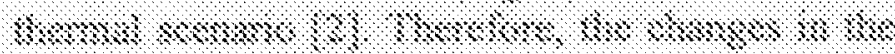


thermal hydrology of the rock mass hosting the emplacement drift are considered insignificant except adjacent to the drift opening, since the duration of the ventilation shutdown is relatively short.

\subsection{Thermal-Mechanical Analysis}

The thermal-mechanical analysis for the off-normal thermai scenarios is performed [5] using the rock mass temperature imported from the NUFT thermal-hydrologic analysis for the off-normal thermal scenarios. Since the temperature changes in the rock mass hosting the emplacement drift is not significant except in region very close to the drift wall, the impacts of the temporary ventilation shutdown on the thermal-mechanical behaviors and performance of the emplacement drift are predicted to be insignificant.

For instance, Fig. 5 shows the major principal stresses at the wall and roof of the emplacement drift for the hottest 1-month shutdown case at the 2year pre-closure time. The simulation is conducted on the weakest Category 1 Tptpll rock (Table 2). The results indicate only a slight increase of thermally induced stresses adjacent to the drift opening. The increase of principal stresses is up to $0.5 \mathrm{MPa}$, approximately only $5 \%$ of the unconfined compressive strength of the Category 1 rock.

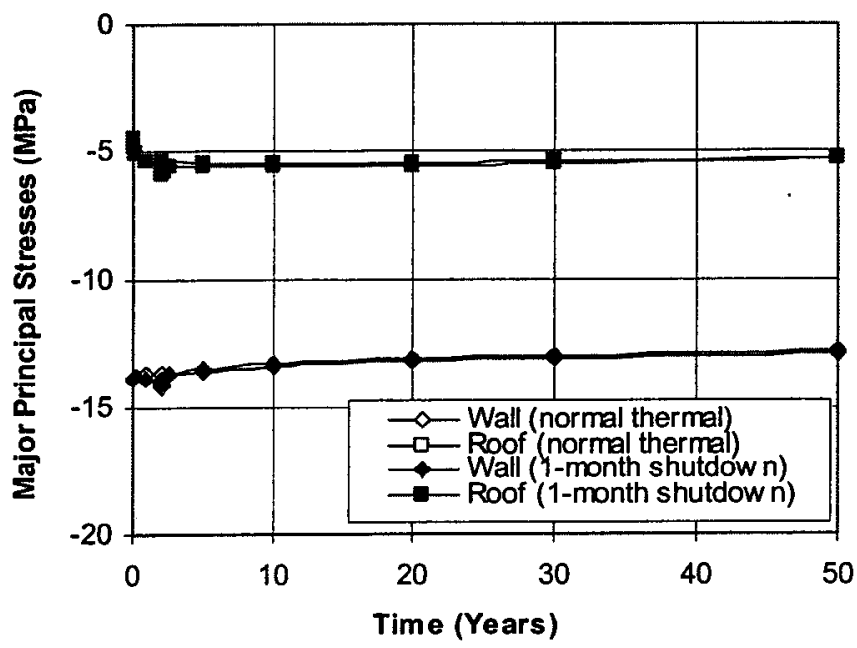

Fig. 5. Major principal stresses at the wall and roof of the emplacement drift for the 1-month shutdown case at the 2-year pre-closure time [5].

Fig. 6 shows contour plots of the strength to stress ratio for the normal thermal scenario and the hottest 1-month shutdown case at the 2-year per-closure time. The plots indicate the contours of the strengthto-stress ratio and the potential yield zone do not show any significant changes in the 1-month ventilation shutdown case compared with the normal thermal scenario. These results suggest that changes in rock stresses are dependent more on how much volume of rock mass is heated and less on the temperature level. The temperature surge with a short duration does not significantly affect the behavior of emplacement drifts.

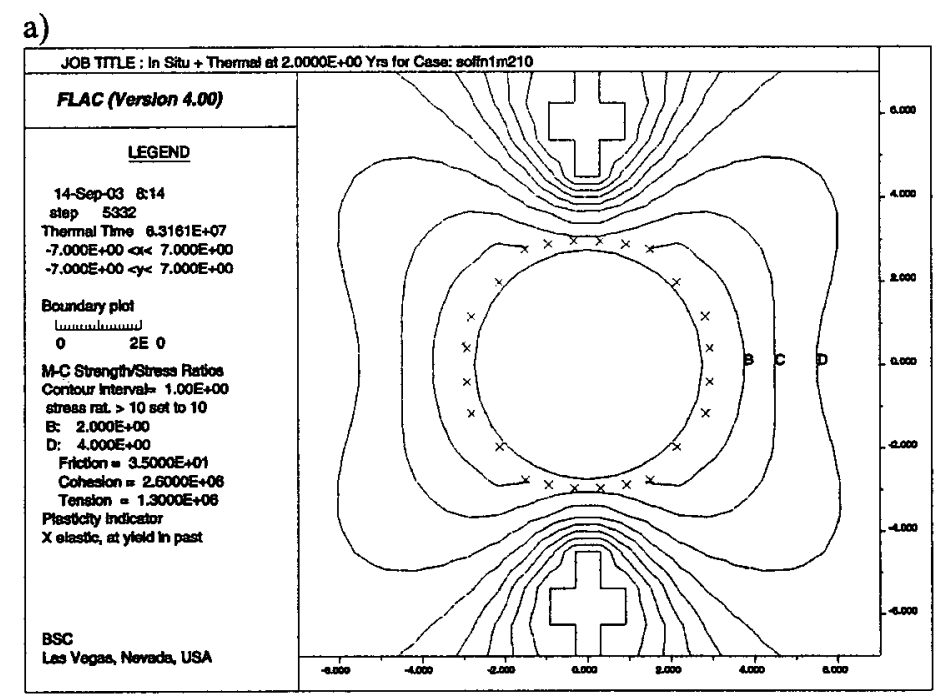

b)

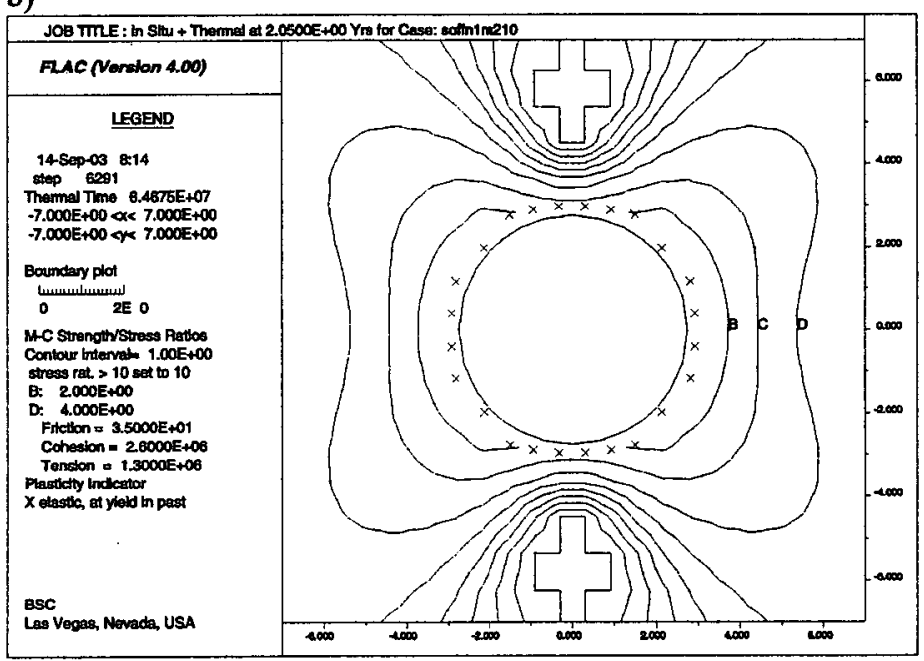

Fig. 6. Contour plots of the strength to stress ratio and potential yield zones (marked as $\mathrm{X}$ ) for a) the normal thermal scenario at 2 years and b) the 1-month ventilation shutdown case at 2 years and 1 month [5].

Based on the thermal-mechanical analysis for the off-normal thermal scenarios, additional degradation and rockfall of the emplacement drifts are predicted to be insignificant. Therefore, it is concluded that the impacts of the off-normal thermal scenarios on the performance and stability of the emplacement drifts are negligible. 


\section{CONCLUSIONS}

The off-normal thermal scenarios that consider the temporary shutdown of pre-closure forced ventilation are investigated to assess the impacts on the thermal-hydrologic-mechanical behaviors and performance of the emplacement drifts in the proposed nuclear waste repository at Yucca Mountain, Nevada [5].

The in-drift heat transfer process of the pre-closure ventilation is analyzed [1]. The efficiency of the pre-closure ventilation in terms of the heat removal ratio is utilized in the thermal-hydrologic analysis. The NUFT thermal-hydrologic software is used to investigate the thermal-hydrology of the rock mass adjacent to the emplacement drift due to the temporary shutdown of ventilation for various shutdown durations at various pre-closure times. The thermal-hydrologic analysis shows a rapid increase of temperature (e.g., approximately up to $30^{\circ} \mathrm{C}$ for the hottest 1-month shutdown case at the 2-year pre-closure time) and a sharp decrease in temperature after the forced ventilation is resumed. However, the analysis also indicates that the impacts of the off-normal thermal scenarios are localized to the drift opening.

The rock mass temperature evaluated from the thermal-hydrologic analysis is used in the thermalmechanical analysis of the off-normal thermal scenarios. The results of the thermal-mechanical analysis indicate only a slight increase of stress adjacent to the drift opening. The changes due to the temporary ventilation shutdown in the strength-tostress ratio and the potential yield zone are minimal. Therefore, the additional long-term degradation and rockfall in the emplacement drifts due the offnormal thermal scenarios are predicted to be imperceptible. Based on this study, it is concluded the impacts of the off-normal thermal scenarios on performance and stability of the emplacement drifts are insignificant.

\section{ACKNOWLEDGMENTS AND DISCLAIMER}

This work was performed and funded under Department of Energy contract DE-AC2801RW12101 for the Civilian Radioactive Waste Management System (CRWMS). Bechtel SAIC Company is the prime contractor for CRWMS.

This paper was prepared as an account of work sponsored by an agency of the United States
Government. Neither the United States nor any agency thereof, nor any of their employees, makes any warranty, expressed or implied, or assumes any legal liability or responsibility for the accuracy, completeness, or usefulness of any information, apparatus, product, or process disclosed, or represents that its use would not infringe privately owned rights. Reference herein to any specific commercial product, process, or service by trade name, trademark, manufacturer, or otherwise, does not necessarily constitute or imply its endorsement, recommendation, or favoring by the United States Government or any agency thereof. The views and opinions of authors expressed herein do not necessarily state or reflect those of the United States Government or any agency thereof.

\section{REFERENCES}

References with an asterisk are Yucca Mountain Project documents that can be requested from the Department of Energy, Office of Civilian Radioactive Waste Management (www.ocrwm.doe. gov).

1. *BSC (Bechtel SAIC Company) 2004. Ventilation Model and Analysis Report. ANL-EBS-MD-000030 REV 04. Las Vegas, Nevada: Bechtel SAIC Company. ACC: DOC.20041025.0002.

2. *BSC 2004. Multiscale Thermohydrologic Model. ANL-EBS-MD-000049 REV 02. Las Vegas, Nevada: Bechtel SAIC Company. ACC: DOC.20041014.0008.

3. *BSC 2004. Drift Degradation Analysis. ANL-EBSMD-000027 REV 03. Las Vegas, Nevada: Bechtel SAIC Company. ACC: DOC.20040915.0010.

4. *BSC (Bechtel SAIC Company) 2004. Subsurface Construction and Emplacement Ventilation. 800-P0CMGR0-00200-000-00B. Las Vegas, Nevada: Bechtel SAIC Company. ACC: ENG.20040304.0002.

5. ${ }^{*}$ BSC 2003. Scoping Analysis on Sensitivity and Uncertainty of Emplacement Drift Stability. 800-K0CTEG0-00600-000-000. Las Vegas, Nevada: Bechtel SAIC Company. ACC: ENG.20031125.0002.

6. Dalvit-Dunn, S., S.W. Webb, R. Walsh, V. Chipman 2004. Yucca Mountain Project Preclosure Ventilation Heat Transfer Analysis: Determining the Mixed Convection Heat Transfer Coefficients. HT-FED200456511. In Proceedings of ASME Heat Transfer/Fluids Engineering Summer Conference, Chariotte, $11-15$ July 2004.

7. ${ }^{*}$ CRWMS M\&O (Civilian Radioactive Waste Management System Management and Operating Contractor) 2000. NUFT 3.0S Users Manual. 10088- 
UM-3.0s-00, Rev. 00. Las Vegas, Nevada: CRWMS M\&O. ACC: MOL.20000920.0092.

8. Itasca Consulting Group 2002. Itasca Software-Cutting Edge Tools for Computational Mechanics. Minneapolis, Minnesota: Itasca Consulting Group. 